\title{
A CONTEXTUAL REVIEW OF THE SELECTED ENGLISH WRITINGS ON JAPAN'S SECRET WAR THEATRE, 1941-1945
}

\author{
Dr Azharudin Mohamed Dali* \\ Zaffar Iqbal Junejot
}

\begin{abstract}
This article explores the English writings, which have substantially examined the Japanese secret war, abroad Indian revolutionaries' collaboration with the Japanese intelligence networks, and British counterintelligence amid World War-II. Further, the paper spotlights the formation of the Indian National Army (INA), the role of Subhash Chandra Bose, and other Indian revolutionaries settled in Southeast Asia and Far East Asia. However, the British portrayed those revolutionaries as 'Japanese Inspired Fifth Column' (JIFC) through their propaganda agencies and efficient organizational setups, including Indian troops. The article also spotlights the covert activities of Japanese in British India, which gathered military and strategic information, and dispatched it to Tokyo. The British thwarted the Japanese espionage networks as well as activities by recruiting the Indians as the double agents, prior they were furthering Japanese interests in India. Unfortunately, the history of British India, English Empire in India and the WW-II bypasses the contribution of abroad Indian revolutionaries and their associations with Japanese-intelligence networks, and their impact upon the Indian nationalist movement during WW-II.
\end{abstract}

Keywords: Japan, Intelligence, WW-II, Secret Agents, Indian subcontinent, Japanese Inspired Fifth Column, Historiography

\footnotetext{
* Department of History, University of Malaya, Kuala Lumpur, Malaysia Email: azharud@um.edu.my

+ PhD Scholar in Department of History, University of Malaya, Kuala Lumpur, Malaysia. Email: zaffarjunejo@siswa.um.edu.my (Corresponding Author)
} 


\section{Introduction}

Sometimes the secret war and intelligence war terms were interchangeably used. However, in either case, it played an integral part in wartime, especially in areas of gathering information about the enemy's intentions, disposition and weaknesses, and strengths. Therefore, knowledge of future actions and plans of the enemy was the asset for the military strategies and leadership in wartime (Jorgensen, 2004).

Intelligence collection refers to advance the strategic purpose of the host country through the network of the secret agents or individual spies. These spies or the networks could supply information regarding the enemy's intentions and even capabilities. The network of spies was bound for dispatching the information to the espionage center for interpretation and analysis. The most important task of the secret agents was to establish the spies' network. It was a prerequisite for the military advancements in Ditto (Douglas, 1997).

The article has set the context of Japanese secret war in the British India, and the Japanese alliance with the abroad-based Indian revolutionaries, and later emergence of INA, and most importantly Subhash Chandra Bose's role in uniting Indians settled in the Far East \& Southeast Asia by inspiring the Indian Prisoners of War (POW) and volunteers to join the INA. The article also provides a background as well as contexts of Japanese espionage networks and British-counter intelligence in WW-II. In British India, the most dominant years were the 1930s, having especial attention to Japanese intelligence activities.

\section{Methodology}

This article is the outcome of the critical examination of secondary sources, which discuss Japan's espionage war, espionage networks, and individual networks that were active from 1941 to 1945. The article examined some relevant primary sources at Oriental Office Collection of the British Library, the Imperial War Museum 
Collection, and the Public Record Office (PRO). However, archival study remained the overarching frame, therefore, other archival sources of the War Office Files and Foreign Office Files were also explored.

\section{Analysis of Literature on Japan's Secret War Theatre (1941-1945)}

The analysis of reviewed literature was organized under the relevant categories. Systematically, these categories spotlight on the literature, which was generated by the war strategists and WW-II specialists. The distinguishing section helps scholars understand Japan's espionage war activities, espionage networks, and individual agents.

\section{British India in amidst of the Great Game}

After India became the British territory, espionage carried out to play its part in protecting the government. The Indian espionage or intelligence agency was launched to support the British position and to assess its internal security. In addition to that, Indian intelligence agencies also indulged themselves in politics; however, it was used to counter the anti-British interest in India.

In the early part of the 19th century, the British thought that Russia was the lead threat to British rule in India (Heehs, 1994). In prepare to thwart the Russian threat; the British took drastic measures to improve the political espionage within India and channelized the military information regarding the northern lands in expectation of Russian advance. Jules Stewart's latest work showed that the information of land pockets unknown to the British authorities was recorded and gathered by various secret undertakings operated through the Great Trigonometry Survey of India. Indians were recruited, trained, and posted to secret assignments to these areas. These spies were known as gurus or pundits, and they 'provided the Government of British India with a wealth of intelligence on the movement of Russian troops beyond the Himalaya and the devious machinations of Central Asian politics, as well as route surveys of 
totally unexplored territories' (Popplewall, 1995, p. 22). In the midst, British espionage observed Russian intelligence infiltration in India.

The Russian design and threat to India were known as 'the Great Game,' a term floated by Rudyard Kipling (1993) in his novel, Kim. The term 'Great Game' referred to gain the control of 'Central Asia' among the secret agents of the British and the Russian Empires during the 19th century and into the 20th century (Bhutani, 2003). The trickery of the 'Great Game' took the attention of academia, and scholars wildly wrote on it as the subject (Allen, 2004). Yapp (1987) argues that the Great Game and India's worried in the 19th century were real instead of an image of non-specialists and had discussed in strategic and political discourse in 1801 before involving strategic thoughts in the 1820s, especially afterward the Russo-Iranian War of 1826 to 28 (Yapp, 1987). The Anglo-Russian agreement of 1907 could not avert the Russian threat to India, but it crept into the 1930s (Hauner, 1981). The new literature about the subject had pinpointed that the Great Game continued till 1947 when the British flew from India (Johnson, 2006). It is pertinent to note that the British Government felt how true the threat existed through Russian influenced communist ideas and movement in India. British intelligence also came to know that the Russians were responsible for training the Indian revolutionaries and communists in propaganda and espionage in the Communist School in Moscow. One of the report states:

The straight evidence shows that 'the Communist International' has established a school in Moscow, where others and Indians are being trained in the conspiracy, science of revolution, and in propaganda, in espionage, in sabotage, and in street fighting... around 30 to 50 Indians and others the various pockets of the [British] Empire are being trained... (LPJ/12/471, 11 April 1934) 


\section{The entry of Japan in British Indian Drama}

Along with Russia, the British also thought Japan as an additional enemy to the British India, and the realization came from the earlier decades of the $20^{\text {th }}$ century. At the end of WW-I, the British Government (Empire) was aware of Japanese interests in the Indian connected areas; it included Nepal, Tibet, and Yunnan. British espionage network in India feared that the Japanese spies' network was active in Tibet; one of them was Yajima Yasujiro (Berry, 1995). Nevertheless, British India viewed that Japan's entry in India was merely around to economic scale and not associated with military or political intentions. At that time, there across the British officers, it was a perception that Japan has no military objectives, and it caused the British Intelligence to focus less on Japan's presence in British India.

Aldrich (2000) stated that until prior to the Pacific War, scanty human resources in terms of the material resources or quality or the first-class skilled human resources were devoted by British Espionage Network to evaluate Japan's threat to British India (Aldrich, 2000). However, this perception did not keep the British at a distance to carefully assess Japan's involvement in those pockets. British officials collected and regularly dispatched the reports to London to add on analysis (Boyd, 1993).

The Japanese espionage network exited before the war around the world. Some of these secret agents were active in Malaya, Burma, Thailand, Borneo, East Indies, and the Netherlands in the camouflage of petty traders, dentists, traveling sales associates, tailors, barbers, goodwill tourists, and photographers (Robertson, 1979). In addition to that, Japanese espionage networks operated under different covers like tourists, traders, diplomats, and businesspeople in the United States and Europe (Matthews, 1993). 


\section{INA and Japanese alliance}

The dramatic situation took a turn during WW-II; afterward, Japan attempted a special effort to gain Indian sympathy for its political cause. The Japanese considered that if somehow India remained under British rule, then Japan's 'the East Asia Co-Prosperity Sphere' would be soon fizzled out. India seemed the last defence line of the British, and it also provided resources of the war, including the workforce. Having it in mind, it became pre-emptive for Japan to establish and extend its area of support network in India. It started to befriend Indian revolutionaries operating in East Asia, especially Rash Behari Bose, Anand Mohan Sahay, and Raja Mahendra Pratap and A. M. Nair. Under the banner of 'Asia for Asians' Japan inculcated anti-British and pro-Japanese feelings among the Indians. The Japanese also agreed with the Indian revolutionaries to open numerous societies and parties in Japan and all-around East Asia. Two of the most important were the INA and Indian Independence League (IIL); the first one played an important role in the IndoJapanese alliance later.

Behari Bose and Mohan Singh then established INA and IIL. This initiative was the most organized way of arousing 'Indian nationalist' feelings and guilt of indebtedness regarding Japan. In 1945, Congress and Nehru verified that INA had got inspiration from a 'passion for freedom of their country, however misguided'. The INA movement had been regarded as 'the most effective and well- organised movement that unnerved the British rulers... [and] spread over most of the states in the Far East' (Ramu, 1998, p. 7).

WWII is a vast historical subject to the historians. Many scholars have investigated numerous issues connected to this period, and one of them was the Quit India Movement (Gayal, 2005). The book India in the Second World by Johannes H. Voight (1987) was especially essential to look at the internal scene in India amid the war, particularly the response of the British and the Indians to the war 
drama. At the same time, the large number of books about WWII were appeared and edited by Bisheswar Prasad. Except for this, there were a total of eleven titles about the Indian Army that has been so for printed and added our understanding and knowledge about WW-II and India (Ray, 1958). Interestingly, some of the scholars have ventured to examine this critical phase from a new standpoint, such as Kamtekar's (2002) in the book 'The Shiver of 1942' and Sanjoy Bhattacharya's (2000) in the book 'British Military Information Management Techniques and the South Asian Soldier: Eastern India during the WW-II'.

Kamtekar (2002) looks at the internal positions in India, and those were the outcome of rumours and unparalleled news propagated orally by different parties. These rumours created some fissures at the internal level in the country. On the other hand, Bhattachary (2000) assessed the propagation of the military and the outfits of censorship structures inside the Indian Army. However, Gyanesh Kudaisya's (2010) in his work 'In Aid of Civil Power: The Colonial Army in Northern India, 1919-42', examined the internal use of the British Indian army for the upkeep of 'colonial state' and for mitigating threats to its authorities. Kudaisya said that the army's security plans, and strategy were critical in holding the British Empires' control even in the war (Kudaisya, 2010). However, Kamtekar (2002) in his book 'A Different War Dance: State and Class in India, 1939-1945' have discussed the relation between the social classes and the state in India amidst the war. His arguments told that the battleground was an accurate perception of the war. However, it examined the state's capability to handle the challenge of its finance, workforce, and other resources (Kamtekar, 2002). However, Tan Tai Yong (2002) examined the alliance between the British and Punjab in helping British war efforts, especially about the recruitment of the workforce for the British Army.

Bayly (2004) also added in to expand the historical treatises about Indian historiography, especially in war times through his British 
Academy's Releigh Lecture entitled 'The Nation within: British India at War 1939-1947'. Bayly's valued contribution pointed out that we could till now enhance the understanding regarding the final days of British Raj and British Imperialism through the reading of Indian history at the wartimes. Previously, the scholars have rarely looked at the work of G. J. Douds' on Indian POWs during WW-II as a subject. Douds' study has revealed that Indian POWs had been marginalized for around 60 years, not only in the literature produce about WW-II; however, in the case of compensations, the POWs were also sidelined. Lately, in 2003, only Gurkhas were given 10,000 Pounds had who fought at the Far-East front (Douds, 2004). These books enhanced our knowledge about India and the WW-II and filled the gaps of the previous published historical books about India in between the 1930s1945.

The presence of Indian espionage networks across the JapaneseOccupied lands in Southeast Asia and the Far East was the highly captivating story of WW-II. However, as previously stated our understanding regarding the subject was still narrow and limited because few works have focused on the topic. However, these studies failed to respond to the questions of how INA espionage activities added into the INA's as well as aggressive Japanese operations towards India or INA secret assignments to India attained any of their aims or how the British intelligence department handle with the INA secret war challenge. However, new studies are essential to address these questions.

\section{INA's secret war}

Till now, various studies conducted about the role of INA in the Indian independence struggle during WW-II. These studies fall into more than one theme: 1) Subhas Chandra Bose as the INA leader, 2) INA battle operations, especially its connection with Imphal and Kohima, and 3) Indo-Japanese coalitions. The work of Leonard Gordon and Hugh Toye's categorized in the first slot, Peter Fay and 
Kalyan Kumar Ghosh in the second, and Fujiwara lwaichi, Joyce C. Lebra, and A. M. Nair in the third theme.

The Indo-Japanese alliance's history during WW-II was identical with Subhas Chandra Bose, and merely a few works look at various perspectives. For instance, only a small number of works have examined at INA's secret agents' activities. From this angle, it was evident that our understanding of the real extent of the Indo-Japanese alliance during wartime is incomplete.

Ghosh (1969) assessed the INA's political impact in India. He stated that no close connection existed between the 'mainstream Indian independence struggle' in India and the INA struggle. He also examined various motivations of the different Indian officers who became part of the INA and the INA's movement with the Indian leadership in Southeast Asia (Ghosh, 1969). This work is referred to as a 'politico-military narrative' (Roy, 1997).

Corr (1975) extending the topic 'The War of the Springing Tigers' tried to join the covert activities of Indians spread over the world with those stationed in India. His version was based on several fascinating occurrences in the revolutionaries' activities, starting from WW-I to the launching of the INA during WW-II. He highlighted that Bose made two fatal judgmental errors, which reduced his position as a leader. The first one was his option to challenge Gandhi, and the second one was his firm belief that he might return to India through the military means, even it was apparent that war had already taken its turn against Japan (Corr, 1975). Joyce Lebra (1977) examined the INA as a diplomatic 'Jungle Alliance' between the expatriate Indians in South East Asia (SEA) and the Japanese. Iwaichi (1983) also has dugout this topic in his work ' F. Kikan: Japanese army intelligence operations in Southeast Asia during World War II'. Albeit, Nair's (1985) book gave a detailed account of the Indo-Japanese alliance as he was involved with the Japanese army establishment even before the war. 
In the case of 'INA-Japanese-Threat' to British India, several options existed. Some of the scholars, like K. K. Ghosh, trusted that the INA was too active in the battlefield in comparison to its other activities. However, other scholars such as Iwaichi and Lebra believed that espionage was more valued than the military offense. Till now, many scholars have successfully examined the infiltration of Japanese intelligence in British Indian affairs. However, none of the scholars unpacked the close connection between the launching of the INA's secret service and Japan's intelligence agencies. Surprisingly, not a single study examines Japan's prior intelligence involvement in India.

The available literature about the INA lacked the focus on intelligence cooperation between the Japanese and the Indians. Iwaichi (1983) and Lebra (1977) have accomplished the most important work. However, as we could infer from their writings that less attention had been given to the Indian espionage efforts. They bypassed to share that Japan's intelligence agency was bound for training Indian agents, and the Indian-Japanese spy schools existed in Malaya and Burma used the Japanese intelligence syllabus, especially of the Nakano School. Iwaichi (1983) and Lebra's (1977) viewpoints about the Japanese alliance pushed backward the INA's spy efforts and the vitality of spy schools in Malaya and Burma. Another book on the subject by Cambridge scholars Tim Harper and Christopher Bayly, also restrained to offer any new insight as they marked merely a few words, not even single paragraph, on INA spy schools (Bayly \& Harper, 1941-1945).

A new addition about INA 'Netaji Secret Service' by Pabitra and Mohan Roy discussed that there was a room to examine the INA's espionage war. However, both failed to add the presence of IndoJapanese spy schools in Burma or to spotlight the several leaders who were part of the secret war tasks. The role of N. G. Swamy and R. Rangavan in portraying the INA espionage action to become a reality, and also role of several other secret agents was ignored in the history of INA. 
Both studies also restrained to highlight the presence of secret agents - who they were, how their induction happened, what was the training, and what were their tasks, missions, and targets. This debate spotted a fresh light on the role of Silver alias Rahmat Khan in Subhas Chandra Bose's anti- British programmes. However, Mihir Bose failed to understand the association between the Japanese and Rahmat Khan, which existed until late 1943.

\section{INA's secret war and British Intelligence}

As evidence surfaced that the Indo-Japanese alliance had become too serious about averting British Indian Army's operations and encouraging Indian troops to be anti-British. It was decided to halt the threat and assure that the protection of the Indian army from INA's propaganda. As part of that plan, the British established the intelligence and counter-intelligence networks, and all of them worked hard throughout WW-II to protect India from INA's actions, including field operations and the secret war. The INA in British India, apart from its patriotic connotation, was mentioned as the 'Japanese Indian Fifth Column' or 'Japanese Inspired Fifth Column' (JIFC) in the British intelligence records.

Several published studies on British intelligence show that attempts were made to protect the British Empire's armies from the Japanese espionage. However, F. H. Hinsley's 'British Intelligence in the Second World War' was considered a recommended reading about the British espionage during WW-II. This book achieved a new mile in British intelligence and history. British Intelligence in the Second World War by Michael Howard (1990) was the final volume of the series. Christopher Andrew (1987) wrote detailed articles "Historical Research on the British Intelligence Community" and "Secret Intelligence and British Foreign Policy, 1900-1939" about the works of British intelligence. Both papers presented a very useful insight into the history of the British espionage. Popplewell's (1987) 'Intelligence and Imperial Defence: British Intelligence and the Defence of the 
Indian Empire, 1902-1924', Aldrich's (2000) 'Intelligence and the War against Japan: Britain, America and the Politics of Secret Service' and Antony Best's (2002) 'British Intelligence and the Japanese Challenge in Asia, 1914-1941' are worth to mention here. Popplewell examined the activities of British intelligence services based in India and London, and it aimed to protect the Indian Empire against in filtered elements. He highlighted the threat by the abroad based Indian revolutionary leaders and movements; the case is of the Ghadar Party. Indian activists abroad, prior to WW-I, commonly feared the organizational efficiency of the abroad intelligence setups of the British Empire.

To gain more knowledge about the threat from Indian revolutionaries, in abroad and India, in 1904, the British in India, established a new service, the Department of Criminal Intelligence (DCI). Its primary function was to gather and relate information collected from the DCI about the Indian local governments and to look at the Indian press abroad and home. The DCI was halted to transform itself from an investigating department. It was restricted only to process the information received from the local CIDs report (Popplewell 1987, p. 49).

Aldrich (2000) focused the association between the British Intelligence, through the Secret Intelligence Service (SIS), Special Operation Executive (SOE), and the American Intelligence Agency, (Office of Strategic Services (OSS). He also discussed Japanese agents' activities in South East Asia and Malaya in the first part. Aldrich has sided the fact that Japanese secret agents were already on important assignments in India, either to gather information or to spread propaganda, prior to the war. Importantly, Aldrich failed to realize the major Japanese actors and their actions in India - T. Kurose of the Nippon Trade Agency and the programmers of the Japanese Consulate in India in gathering information and supporting proJapan propaganda. In addition to that, he also merely looked at the contribution of Rash Behari Bose as the main lead in 'Japanese Indian 
Mission' while bypassing some other leaders, one of them was Anand Mohan Sahay. He also ignored the contribution of many Indian focal points linked to the Japanese army like Usman Khan and A. M. Nair, and most importantly, ignored the reality that the INA also contained secret operations. Even though he failed to document the fact about the INA-Japanese spy support mechanism, known as the 'JapaneseInspired Fifth Column'. He has strived that there was a low scale INA-Japanese spy actions against British India (Aldrich 2000, p. 163).

Antony Best's (2002) book was substantial as well as thoughtful documentation about the success as well the failure of British intelligence programmes and policy in Asia in the thirty years moving up to WW-II. Undoubtedly, this book was essential, and it portrayed some surprising accounts of British intelligence policy (1914 to 1945). He artistically pinpointed to highlight how intelligence 'contributed to the process of Anglo- Japanese alienation and eventually to the outbreak of the Pacific War' (Best 2002, p. 10). It was impressive to note that the British had few military officers trained in the Japanese language. It was surprising that out of the 34 British and Indian army officers trained in the Japanese language since WW-I, only 16 were in active service till 1938, and merely three had attended British India's military staff colleges. It was surprising to know that Britain did not realize Japan as a big challenge until just before the Pacific War. Best also explored Japanese spy activities in Malaya before the war, however, he failed to count similar activities in British India. Simultaneously, he also failed to scan at the challenge of the INA secret assignment against British India and ways the British intelligence agency, such as the Deception Division, carried out counter-intelligence actions to halt this threat. He also portrayed a rich narrative on Anglo-Japanese history and diplomatic relations in the inter-war period by examining freshly released intelligence records, notably the HW12 series at PRO (Best, 2002, p. 85-100).

One of the crucial decisions taken by British intelligence was to engage Indian-Japanese agents to work for them as 'double agents.' 
This issue was left stagnant by previous studies. Only Holt (2005) and Hauner (1981) have referred this matter in their studies. Hauner's work revealed the fact that Rahmat Khan was working for the German intelligence agency but failed to pinpoint that he was also engaged with the Japanese and was the man who caused the failure of Subhash Chandra Bose (Hauner, 1981). Another fascinating book about the subject was Thaddeus Holt's 'The Deceivers'. Many chapters of the book discussed the allied deception activities in WWII. It also portrayed the activities of INA 'double-agents' and their traitorous activities and how British intelligence was able to engage them in 'British- Counter-Intelligence-Networks' (Holt, 2004). However, the British succeeded in engaging former INA agents as 'Double Agents', which shows that the security units, in Indiaintelligence agency, Indian Army, and in other defense forces, had operated very well. These organizations were more able to refute any strived by the INA agents to disturb India. The managerial ability to manage the Indian security establishments, such as the intelligence agency and Indian army, proved that British India was capable of staying more in India, even beyond the end of the war. However, it was a fact that the British succeeded in blocking the external INAJapanese war measures, they enormously failed to focus the more serious threat of the home-grown Indian political movement after the war. Consequently, India became free from British yoke in 1947.

Douglas Ford's (2006) exploring on Britain's intelligence war against the Japanese has examined the more common terms of war, however, did not examine the INA secret activity in detail. He has almost ignored the relationship between the Japanese and the INA though his work was vital because it forwarded, in more detail, the British ability to address the Japanese intelligence onslaught in war times.

The works referred above have added to the defense of the Indian Empire and the history of British intelligence. Altogether, these studies have contributed, in various ways, to the preparing of a new area in Indian history. However, Lebra (1977) stated that Japan did 
not seem to have a considerable volume of information regarding, even in headquarters and only a few civilian authorities in Japan know about India's ground realities. There was non-existing of any organization, team, or body that could be called the 'Indian lobby' in Japan. Further, Lebra states that India was a distant concern for Japan in 1941.The same opinion was aired by Fujiwara Iwaichi (1983) in his memoir.

The espionage war against the British in India before WWI-I was a part of the abroad based Indian revolutionary activities, especially, among those who lived in East Asia. As war became predictable, the Indian revolutionaries settled in the Far East jointly regarded the Japanese option, the only practice that could help them in their longhalted war against British India. Importantly, the decision to associate with the Japanese by Indian revolutionaries in Japan, especially, Rash Behari Bose, A. M. Nair, and Anand Mohan Sahay, motivate the Indian POWs and Indian migrants. It was a fact that the Japanese used all of them to pass a message to the Hindustani population in East Asia that the Japanese were their saviour in the war against the British in India. Japan also considered the Indian revolutionaries as associates, who were there to help them to control the Asian lands. Simultaneously, regarding the non-revolutionary Indian population, the Japanese succeeded in Burma, Malaya, China, Hong Kong, and French Indo-China to expect them to rely on the Japanese to live a better life.

The primary issue in the British Army was loyalty, particularly, when it was concerned about the Indian troops. The local troops made up a vital part of the whole of the British Army. Consequently, the British officials were heavily relying on Indian troops to protect the British Empire. The point of loyalty among the British-Indian troops in Japanese-occupied lands needs exploration, and it is still a void area in the British-Indian history. 


\section{Conclusion}

History of Japanese intelligence has attracted more interest among the historians. The collaboration between India and the INA was welldocumented as seen in the various writings. However, Japanese activities in South Asia particularly in India, Afghanistan, Nepal and Tibet are still in small numbers. This will be opened to full research as the Japanese involvement in espionage activities in the particular region.

Besides, the Anglo-Japanese scene and relations in the mid of 1930s, till WW-II, are thoroughly scanned. However, the lead focus is on how the Anglo-Japanese espionage infiltration opaque the relationship between Japan and the British in the pre-WW-II period. A thorough examination of the relationship between the Japanese and Indian, especially, INA and its secret agents were carried out. More exploration dictated in-depth discussion about several events and attempts of the Indian revolutionaries in Japan, and the Far East. However, the significant contribution of Rash Behari Bose, who contacted the Japanese officials and coordinated the revolutionary actions in Siam. Importantly, the article unpacks the formation of the INA secret efforts and the induction of the Indo-Japanese alliance, especially in the secret war. The most crucial part of the article is the role of INA's secret services operations against the British in India. The pertinent aspect of the article is to who were lead actors of the INA spies' network, how they got their training to sabotage and propaganda. Most importantly, it explains the establishment of INA, its secret service, an alliance with the Japanese intelligent service, and the joint war against the British interests in India. It has also determined the British intelligence's counter attempts to foil the INA's secret war in British India and abroad, thereby sheds new light on INA secret war, its alliances with the Japanese and history of INA, and its leaders. In addition to that present article suggest a fresh way of exploring the INA history in challenging the British colony through its secret means. Second World War itself presented an inviting 
opportunity for the revolutionaries, the INA, and Japan. This article is an attempt in the INA historiography to examine the unseen instruments in the INA war against the British. In a restrict sense, the present article is an extension of the body of literature about the Indian revolutionary abroad, INA, and Japanese espionage war theatre and British counter-intelligence in British India. The present article unpacks the historical and contextual linkages that Japan's intelligence had focused on gathering intelligence information in British India before the Pacific War. It has strived to fill the void left by espionage studies about British India in the pre and amidst the war period, especially alliances of Japan's espionage networks and individual operators.

\section{References}

Aldrich, R. J. (2000). Intelligence and the war against Japan: Britain, America and the Politics of Secret Service. Cambridge: Cambridge University Press

Alka, S. (1992). The Quit India Movement. Delhi: H. K. Publications

Allen, Ch. (2004). Duel in the Snows: The True Story of the Young Husband Mission to Lhasa. London: John Murray Pubs Ltd

Allen, L. (1976). The End of the War in Asia. London: Hart-Davis Macgibbon

Allison I. (1958). Spy Ring Pacific. London: Weidenfeld and Nicolson

Andrew, Ch. (1987). Secret Intelligence and British Foreign Policy, 19001939' In Ch. Andrew, and J. Noakes (Eds.) Intelligence and International Relations, 1900-1945 (pp.18-19). University of Exeter

Baksh, S. R. I (1990). Congress, Muslim League and Partition of India. New Delhi: Deep \& Deep

Bayly, C. A. (2004). The Nation Within: British India at War 1939-1947, Raleigh Lecture on History. The British Academy

Bayly, Ch., and Harper, T. (2010) Forgotten Wars: Freedom and Revolution in Southeast Asia. Harvard University Press

Berry, S (1995). Monks, Spies and a Soldier of Fortune: The Japanese in Tibet. London: Athlone 
Best, A. (2992). British Intelligence and the Japanese Challenge in Asia 1914-194. Hampshire: Palgrave Macmillan

Bhakari, S. K. (n.d). Indian Warfare. Delhi: Munshirarn Manohar Lal

Bhattacharya, S. (2000). British Military Information Management Techniques and the South Asian Soldier: Eastern India during the Second World War. Modern Asian Studies, 34 (2), 483-510

Bhutani, V. C. (2003). Great Game Revisited. The Indian Historical Review, 30(1-2).

Boesche, R. (2003). Kautilya's Arthasastra on War and Diplomacy in Ancient India. The Journal of Military History, 67 (1), 9-37

Boyd, C. (1993). Hiller's Japanese Confidant: General Oshima Hiroshi and Magic Intelligence, 1941-1945. Kansas: University Press

Corr, G.H. (1975). The War of the Springing Tigers. University of Michigan

Douds, G. C. (2004). The Men Who Never Were Indian POWs in the Second World War. South Asia: Journal of South Asian Studies, 27(2), 183-216

Fay, P. W. (1994). The Forgotten Army. India's Armed Struggle for Independence 1942-1945. University of Michigan Press

Gayal, P. K. (2005). Battle of India's Freedom Movement. New Delhi: Vista International Publications

Ghosh, K. K. (1969.). The Indian National Army, Second Front of the Indian Independence Movement. University of California

Hauner, M. (1981). The Soviet Threat to Afghanistan and India 1938-1940. Modern Asian Studies, 15(2), 287-309

Heehs, P. (1995). India's Divided Loyalties. History Today, 45(7). Retrieved from: https://www.historytoday.com/archive/indias-dividedloyalties

Heehs, P. (1994). Foreign Influences on Bengali Revolutionary Terrorism 1902-1908. Modern Asian Studies, 28(3), 533-556

Holt, T. (2004). The Deceivers: Allied Military Deception in the Second World War. Holt, T. (2004). Pairs: Weidenfeld \& Nicolson 
80 A Contextual Review of the Selected English Writings on Japan's Secret War Theatre

Iwaichi, F. (1983). F. Kikan: Japanese Army Intelligence Operations in Southeast Asia during World War II. Heinemann Asia

Johannes, H. V. (1987). India in the Second World War. New Delhi: Gulab Vazimni for Arnold-Heinemann

Jorgensen, Ch. (2004). Hitler's Espionage Machine. Guilford: The Lyon Press

Jules S. (2006). Spying for the Raj: The Pundits and the Mapping of the Himalaya. London: Sutton Publishing

Kamtekar, I. (2002). The Shiver of 1942. Studies in History, 18(1), 81-102

Kudaisya, G. (2010). In Aid of Civil Power: The Colonial Army in Northern India, 1919-42. The Journal of Imperial and Commonwealth History, 32(1), 41-68.

Lebra, J.C. (1971). Jungle Alliance: Japan and the Indian National Army. Donald Moore for Asia Pacific Press.

Leonard A. G. (1989). Brothers against the Raj: A Biography of Sarat and Subhas Chandra Bose. New Delhi: Viking

Matthews, T. (1993). Shadow Dancing-Japanese Espionage Agents against the West, 1939-1945. London: Robert Hale

Popplewell, R. J. (1995). Intelligence and Imperial Defence. London: Frank Cass

Ramu, P. S. (1998). Azad Hind Fauj (INA) and the Freedom Movement. New Delhi: Freedom Movement Memorial Committee.

Ray, G. (1858). Official History of the Indian Armed Forces in the Second World War 1939-45: Post-war occupation. Calcutta:S.N.

Robertson, E. (1979). The Japanese File. Hong Kong: Heinemann Asia.

Roy, K. (2003. War in Indian History. The Indian Historical Review, 30(1), 3345

Yapp, M. A (1987). British Perceptions of the Russian Threat to India. Modern Asian Studies, 21(4), 647-665

Yong, T. T. (2002). Mobilisation, Militarisation and Mal-Contentment: Punjab and the Second World War. South Asia: Journal of South Asian Studies, 25(2), 137-151 